\title{
Personal Utopia: The "Good Life" in Popular Religion and Literature in Contemporary Sweden
}

\author{
By Daniel Enstedt \& Kristina Hermansson
}

\begin{abstract}
This article examines the discourse of the "good life" in popular religion and literature in contemporary Sweden. The results indicate that new spiritual movements, such as mindfulness and the Enneagram, place traditional transcendental goals within the individual, immanent self and that the utopian ideals, such as individual wellbeing and happiness, expressed in popular literature are to be achieved through changing individuals' attitudes rather than their material and structural circumstances. Furthermore, this understanding of the individual relies on a culturally based discourse in which medicalized, therapeutic language, what Michel Foucault called "bio-power", defines humanity and the human condition. This cultural discourse centers on the individual's potential and responsibility to change dysfunctional habits, situations, and relationships, while structural, contextual, and situational solutions are ignored. The Swedish popular literature and religion examined here both express this discourse and constitute an important new form of authority when it comes to articulating new utopian ideals in everyday life, at work, and in family life.
\end{abstract}

Keywords: Medical humanities, Medicalization of society, Therapy culture, Cultural studies, Scandinavian studies, Popular religion, Popular literature.

Enstedt, Daniel and Kristina Hermansson: "Personal Utopia: The Good Life in Poular Religion and Literature in Contemporary Sweden", Culture Unbound, Volume 10, issue 1, 2018: 128-150. Published by Linköping University Electronic Press: http://www.cultureunbound.ep.liu.se 


\section{Introduction}

In The Medicalization of Society (2007), sociologist Peter Conrad examines the medicalization of Western society, in which problems formerly deemed to be nonmedical have been increasingly conceptualized and understood by the medical sciences as disease or mental defects. This societal change has already been discussed in The Triumph of the Therapeutic: Uses of Faith after Freud (1966), in which Philip Rieff discusses the phenomenon in the light of Christianity's diminishing influence on society and more than a decade later, Christopher Lasch emphasized not only the failure of Christianity but also the collapse of authorities in general (Lasch 1978). ${ }^{1}$ By framing human problems in medical terms, rather than in religious, poetic, or literary terms, a different and novel conceptualization of human life emerges (Johannisson 2009). The increasing medicalization of society has profoundly changed not only social life itself but also its literary, religious, and spiritual expressions (Conrad 2007: 14). According to Eva Illouz, who has studied this phenomenon in an American context, the medicalization of society has led to the combination of self-help strategies and popular religions (Illouz 2008: 157). This fusion can also be seen in Swedish culture and we examine it in this article. The recently developed research field of medical humanities examines the medicalization of society and the possible consequences of this development (Bates, Bleakley and Goodman 2014). By studying a selection of materials from Swedish popular religion and literature, we explore notions of how to live a good, healthy, and thriving life. In this exploration, the article aims to shed light on a cultural change affecting Swedish society as a whole.

Expressed in the material examined in this article, and intertwined with the increased medicalization of Western society, is an ongoing discursive renegotiation of the individual and family life. The medicalization of society raises questions about the kind of life that is held up as good, healthy, and desirable; and about the kind of life that is described as dysfunctional, unhealthy, and not worth living. This article examines contemporary expressions of popular religiosity, spirituality, and literature, in order to critically examine what Michel Foucault has called " $t$ the fundamental codes of a culture-those governing its language, its schemas of perception, its exchanges, its techniques, its values, the hierarchy of its practices-[that] establish for every man, from the very first, the empirical orders with which he will be dealing and within which he will be at home" (Foucault 2002: xxii). We consider new forms of religion and spirituality, such as mindfulness and the Enneagram, in contemporary Swedish society, and new forms of popular cultural production and narratives, especially "mom chronicles" and "mom blogs." The article emphasizes how the medicalization of society is received, negotiated, and expressed in late modern Swedish society, focusing on a selection of new cultural production. 


\section{From Religious Utopia to Individual Goals}

Much of the Western literature and popular religion of today concern notions of how to live a good life. This question is far from new, having been discussed in Aristotle's Nicomachean Ethics as what he called eudaimonia. He used this term to describe the human potential to develop one's own life into the best possible life (Aristotle 2011). The echoes of eudaimonia still resound in popular culture and in popular psychology, self-help literature, and New Age spirituality. Two terms associated with ideas about how to form a good life and a good human society are "utopia" and "utopian imaginaries." In our contemporary cultural context, utopias primarily focus on the individual and the individual's ability, often on a rational basis, to recreate his or her own life and situation. From the 1500s onwards religion, often Christianity, was central to the utopias formulated. The early connection between religion and utopian ideas can be seen in Thomas More's groundbreaking novel Utopia from 1516, in which Christian beliefs are merged with political ideas. With More's Utopia as a prototype, a series of utopian fictions appeared during the 17th and 18th centuries, one of which was Daniel Defoe's Robinson Crusoe, published in 1719. The growing critique of the religious content of utopian thought, however, developed into the new secular, political utopias of the 19th century (Claeys 2010).

Contemporary utopias, however, are more about individual transformation and less about social change, even within a religious context. In addition, the focus has shifted from a transcendent point of reference to an unalloyed immanence. Instead of being concerned with the afterlife and intangible ideals, utopias now situate their goals in the world, with concrete aims that the individual can attain with the right knowledge, technology, and effort (Vieira and Marder 2012). Swedish theologian Ola Sigurdson suggests that hygiene "can be seen as a root metaphor" in both the fictional and factual construction of the Swedish welfare society from the 1930s onwards (Sigurdson 2014: 45). The effects of this central metaphor have ranged from an emphasis on personal hygiene, the downplaying of local dialects, and the politics of education, to new aesthetics, architecture, and city planning. In short, the modern bio-political idea of hygiene, and its younger sibling, the idea of health and wellbeing (Kardemark 2013), have affected Swedish society in a variety of ways. During the 20th century, when the Swedish Social Democratic Party dominated the political landscape and implemented the political ideals of "the people's home" (folkhem) and of equality, the hygiene metaphor had a significant impact on society.

The fundamental changes that Swedish society has undergone during the last century include an increase in individualization; and the onset of modern forms of globalization, societal differentiation, and secularization (Demerath 2007). In light of such changes, it appears that individual involvement in religion has 
declined, and that Swedish citizens have lost their religious faith in favor of more secular ideas and perspectives. Sweden has been described as one of the world's most secular countries (Norris and Inglehart 2011: 60, 277-278). "In terms of religion," as Peter Berger, Grace Davie, and Effie Fokas succinctly put it, "India and Sweden can serve to mark the antipodes of religiousness and secularity" (2008: 12).

However, alongside the more established and conventional religions, new forms of religiosity are emerging in such diverse locations and arenas as health centers, spas, and gyms; in pilgrimages; in qigong, mindfulness and Tai Chi classes; at schools, hospitals, and workplaces; and in family counseling sessions (Hornborg 2010, Hornborg 2012, Frisk and Åkerbäck 2013). These new expressions of religion can be regarded as continuations of the New Age movement that began to take shape in Sweden in the 1970s (Frisk 1998, Hammer 2010). As with the New Age movement, these expressions cannot be immediately categorized as "religious", but should rather be denoted "spiritual" (Hammer 1999: 336-363, Hornborg 2012). This ambiguity has increased in recent years as more explicit spiritual beliefs, pertaining to such concepts as divinity, the cosmos, spirituality, and energies, have been downplayed by the movement itself. This new religiosity has allied itself with evidence-based medicine and various forms of science.

These new religious expressions center on the idea that every person is the carrier of an internal "higher self"-the "HS factor"-with a potential for development (Heelas 2002: 370). Such a shift in religious emphasis has implications for the conception of God, who "is thus identified with humans' inner potential rather than with any supernatural being" (Frisk 1998: 18). ${ }^{2}$ In a New Age spirituality context, sacralization is occasionally associated with pseudoscientific language and with beliefs about the body and health, wellbeing, and personal development, while its religious aspects are toned down, which can make it difficult to identify as a religion.

\section{Popular Religion and Spirituality in Sweden}

Mindfulness is a relatively new form of religious practice that is often described as "Western Buddhism". Mindfulness-based stress relief has spread widely in Sweden, not only in cognitive behavioral therapy, but also in the public health sector, at health centers and workplaces, in families, and in individuals' religious life (Plank 2014). Although mindfulness is one of the most visible expressions of the latest wave of new spirituality, it is not an isolated phenomenon in contemporary Sweden. Instead, it encapsulates a way of thinking at the boundary between belief and knowledge, religion and science (see, for example, Plank 2011: 213-220). Mindfulness is part of what Anne Harrington (2008) has called the "Eastward 
journeys" of Western societies, in which the reception of so-called Eastern, or Asian, philosophies and religions has increasingly been aligned with issues of health and medicine, especially stress-related problems.

Although mindfulness occupies a leading position among new forms of religiosity in contemporary Sweden, it is far from alone. Another such phenomenon in recent years is analysis of the Enneagram, which distinguishes between the essence-the "true inner self"-and the personality, which hinders us from development and "spiritual awareness". However, personality is not irrelevant: Enneagram analysis defines nine personality types, each with distinctive characteristics and traits. It is necessary to know which personality type one belongs to before one's "spiritual journey" can begin. In fact, Enneagram advocates often mention mindfulness as an appropriate spiritual practice to combine with the Enneagram (Riso and Hudson 1999: 359). The Enneagram has its origins in early 20th century Russia, in an esoteric movement associated with George Ivanovich Gurdjieff's (1866-1949) mysticism and speculative cosmology (Enstedt 2015a). The nine personality types, which were added to the Enneagram much later, can be combined in more or less successful ways. Some combinations, for example, are more suitable than others in the workplace (Palmer 1995; Lapid-Bogda 2010). Swedish executives, in adopting the Enneagram, also learn how staff should be organized to work in a more "satisfactory" - by which is meant more profitable, healthy, and productive-way. The Enneagram is also used when new staff-members are hired. The personality type of a prospective employee is considered during the recruitment process in relation to how this type fits with other personality types already present in the workplace (Palmer 1995: 249-401). It is primarily coaches from Enneagram institutes who possess the knowledge of how to apply the Enneagram principles in a work environment, and they sell courses, not only to companies, but also to local governments.

In the anthology Medarbejder eller modarbejder (2007), Kirsten Marie Bovbjerg points out that such courses include "disciplinary techniques that are designed to make employees able to handle/accept the stress level in the company" (2007: 75). The successful implementation of these new religious disciplinary techniques is, furthermore, claimed to be important for the continuing well-being of the personnel and productivity in the workplace, not least because these techniques are intended to reduce work-related stress, and in this way create balance and harmony in the workplace. Altogether this generates, as Joel Haviv puts it, "a new myth about the employee's eternal development and self-realization through special religious techniques" (Haviv 2007: 160). However, this myth can also have a downside, especially if the employee lacks the necessary potential and the preconditions required for the techniques to be implemented. In addition, the individual-centered efforts that characterize these new religious techniques can 
be misdirected if the workplace is struggling primarily with structural problems (Hornborg 2012: 198).

The following section scrutinizes how the Enneagram has been received in an established religious context and in a nonreligious context. The latter is represented by the Gothenburg-based Enneagramskolan (the Enneagram School) of former IT consultant Elisabeth Wiktorén. Wiktorén is an Enneagram instructor who has written a book and produced a documentary film about the Enneagram. The Enneagram School emphasizes personal development, self-awareness, and wellbeing for private citizens, and for managers, executives, and teams. The more explicit religious context studied in this article is the Church of Sweden. Deacon Marie Bernéli has, like Wiktorén, written a book and gives lectures about the Enneagram, usually in a Church of Sweden setting.

In the 1990s, Don Riso and Russ Hudson wrote The Wisdom of the Enneagram (1999), often referred to as the modern "Enneagram Bible." Central to their understanding is the statement that "the Enneagram is the universal insight that human beings are spiritual presences incarnated in the material world and yet mysteriously embodying the same life and Spirit as the Creator. Beneath surface differences and appearances, behind the veils of illusion, the light of Divinity shines in every individual" (Riso and Hudson 1999: 9). Interestingly, Wiktorén presents another interpretation of this insight in her book that differs from the mystical point of view presented by Riso and Hudson by emphasizing "humans' inner potentials rather than to God" (Wiktorén 2007: 17). Instead of talking about God, Wiktorén concentrates on the inherent power and potential underlying every personality type's "mask". It is the "mask" that hinders people from developing and expressing their full potential. The Enneagram sheds "light on the true self," that is the "I" that is behind the mask of personality, "our false self." Importantly for Wiktorén, however, that "I" is not God.

Wiktorén has thus replaced "God" with "our original power". The goal is to "become a harmonious and well-functioning human being" rather than to get in touch with the divine self (Wiktorén 2007: 10). It is not about surrendering to any transcendent God, but rather liberating oneself from the influence of the false personality over one's life, in favor of a truer, more original existence. Each personality, according to Wiktorén, must "rediscover the inner core, to dare to live life in love and to take responsibility for one's own life" (2007: 10). When Wiktorén uses terms such as "virtue" and "mortal sin", these are nonreligious concepts, clearly detached from the more established Christian context (Giddens 1991). Such uses of theological terms are associated with what Anne-Christine Hornborg calls "a new form of spirituality that is emerging in the Western world, which is characterized by the notion of a hidden essence within every person that can be developed in order to live life to the fullest" (Hornborg 2014: 148). 
Wiktorén describes a fundamental conflict between the essence, "our inner core", and the personality, "our false self". At the same time, all humans are attributed with "a special powerful ability that is our virtue, which will help us reach and develop the essence" (Wiktorén 2007: 24). The problem is that "fear, shame, and anger" cause us to lapse into the opposite of virtue, which Wiktorén calls "fixation" or "autopilot". The use of these terms is associated with another central concept in Enneagram teaching, namely, that of the sleepwalker (Enstedt 2015b). Personal development is about "waking up", getting rid of our fixation and letting the Enneagram-more specifically, virtue-lead us "back to our original strength" (Wiktorén 2007: 49).

Wiktorén demystifies and secularizes the Enneagram. She replaces religious and spiritual concepts with secular ones, and excludes the transcendental referent of Enneagram teachings. Her interpretation emphasizes wellbeing and health to a greater extent than the spiritual maturity that Enneagram teaching is associated with elsewhere. Furthermore, Wiktorén's interpretation of the Enneagram is based on concepts taken from psychology and clinical psychiatry. This psychologization of religion is also discussed in a wider context of New Age religions (see, for example, Hanegraaff 1996).

While Wiktorén removes associations with religion and spirituality from the Enneagram, other Enneagram teachers do the opposite. For Deacon Marie Bernéli, who is active in the Church of Sweden, the "deepest goal [of the Enneagram is] to guide people to a more complete life in God's love" (Bernéli 2009: 10). The most notable difference between Wiktorén's and Bernéli's Enneagram interpretations lies in how they relate to God, the soul, and spirituality. The Enneagram is, according to Bernéli, about "our relationship with 'the Holy" ("the Holy" being equivalent to the Christian God) (Bernéli 2009: 9). Bernéli places Enneagram teaching into a Christian theological context and highlights the importance of biblical texts and a life of prayer for one's relationship to God: "The Enneagram [symbol] is an expression of 'the sacred' and reflects the face of God"; the nine Enneagram types are "nine different aspects of God's nature" (2009: 15-16).

Humans, according to Bernéli, crave God: "We bear a longing for our true origins-as a kind of memory of 'paradise" (2009: 218). This yearning has become clouded by egocentric desire and by "things that attract us with material, psychological, and spiritual satisfaction" (Bernéli 2009: 219). The essential problem faced by humans, Bernéli maintains, is that "we are seeking God, but end up over and over again in ourselves" (2009: 31). When we are born, Bernéli declares, we are in symbiosis with the world and "see ourselves as one with everything" (2009: 31). Such a way of life dissolves as a division develops between the child and the world, a division that enables the ego to form. While a concept of "self" is fundamental to human life, this concept is, according to the Enneagram, also a 
central problem. The development of a concept of self gives rise to an egocentric desire that alienates us from God. People put themselves in the place of God when they attempt to save themselves by living up to their own ideals (Bernéli 2009: 47). However, as Bernéli puts it, "we cannot save ourselves and we do not have to" (2009: 49).

In her description of the Enneagram, Bernéli uses not only Christian terminology but also language from clinical psychology. Terms such as "defense mechanisms", "the unconscious", "projection", "rationalization", "I-concepts", and "fixation" are common. The established understanding of the term "defense mechanisms" in psychology is that these are "essential ego-functions that are unknown to the person himself and are as important for psychological survival as the body's immune system is for its physical survival" (Cullberg 2001: 95). According to the Enneagram, in contrast, defense mechanisms prevent humans from being present in the moment. While defense mechanisms are widely regarded as normal and necessary from a psychological perspective, they appear in Enneagram teaching as the basic problem, that which alienates humans from their essence. Such a view is presented also by Riso and Hudson: "It took many years to build up our ego defenses, so we cannot expect to dismantle them overnight. Our soul has its own wisdom, and it will not allow us to see anything about ourselves (much less release it) until we are truly ready to do so" (1999: 45).

The nine Enneagram types are "in their origin, nine different aspects of the nature of God, the way God is manifested" (Bernéli 2009: 15). Wiktorén mentions that the Enneagram has been called "the face of God", and discusses the ability to balance and integrate the nine aspects of the Enneagram: "when we succeed in balancing the nine aspects, our job as humans is completed. In the Christian tradition, it is said that the one who has achieved this is Jesus" (Wiktorén 2007: 34). Both Bernéli and Wiktorén appear to be influenced by aspects of C.G. Jung's analytical psychology, although the only direct reference to Jung is in connection with the Myers-Briggs Type Indicator (MBTI), which Wiktorén mentions. The purpose here is not to lapse into Jungian exegesis, but rather to point out how some key aspects of the contemporary Enneagram have an affinity with Jung's analytical psychology. This is not surprising, however, because Jung, as Olav Hammer has pointed out, has long been appreciated in new religious circles (Almqvist and Hammer 1999; Hammer 2010). As in Jung's writings, the localization of God within humans is not entirely clear in Bernéli's interpretation of the Enneagram. Humans should not try to save themselves, but should instead "believe in the power that exists outside the self, which can and wants to help"; when people "let go", they not only meet their "true self", but "also God, who ever since the beginning, has been living in the inner self waiting for us to come home" (Bernéli 2009: 91). God is identified as a power that transcends humans, but simultaneously exists in their hearts. 
In Sweden, the reception of the Enneagram has been accompanied by an almost total rejection of its religious and spiritual associations, and focus has been on personality types and their development. The Enneagram has, however, been incorporated by some into a Christian theological context that accommodates talk about God and the divine. While a demystified, rationalized version of the Enneagram has made the teaching available in public contexts, in workplaces, and to Swedes who do not consider themselves either religious or spiritual, a religious version of the Enneagram has made esoteric and spiritual Enneagram teaching possible in an explicit, established religious context. At the same time, the religious and the secular contexts comprehend the Enneagram in similar ways, to a certain extent. A central feature of the Enneagram in Sweden is its focus on individuals and their potential to develop into more complete, healthier humans. The language and practices of those who work with the Enneagram differ, however, between the two contexts, since they have different requirements with respect to creating credibility, legitimacy, and discursive space. It is unsurprising that the religious, ecclesiastical setting provides a space for the Enneagram in which God is spoken of in positive terms, generally in harmony with the Church's views and with established Christian concepts such as sin, salvation, grace, and reconciliation. In contrast, Wiktorén does not refer to God or to spirituality: religion and religiosity instead appear as historical residue and as contributors to an individual's psychological problems. Wiktorén uses pathological concepts from psychology. The nonreligious context and the business world, which are the abode of Wiktorén's understanding of the Enneagram, require another language. Meanwhile, the similarities between Wiktorén's and Bernéli's interpretations can be understood from the basis of Paul Heelas' (2002: 370) "HS factor", according to which every human being contains a hidden essence, an inner core, that stands in contrast to personality, which in turn prevents the development of the healthy individual living a good life.

Meanwhile, the search for common ground between Wiktorén's and Bernéli's interpretations can be considered the basis of Paul Heelas' (2002: 370) "HS factor", according to which every human being contains a hidden essence, an inner core, that stands in contrast to the personality. This opposition, in turn, prevents the development of the healthy individual and prevents a good life.

\section{Self-help Manuals in Contemporary Sweden}

The amount of self-help literature published has expanded vastly in recent decades. A prominent feature of this literature is its tendency to offer individual solutions to problems of structural origin, such as unemployment. Self-help literature aims to guide readers in managing their problems on an individual level, 
by changing their thoughts and actions rather than their outer circumstances. "Will-power" and "self-esteem" are two key words here. In several respects, as Füredi demonstrates, the self-help genre connects very well with current neo-liberal politics, which holds individuals to be fully responsible for their own success. Füredi's critical analysis not only applies to Britain and the USA, but is also relevant to the situation in Scandinavia: "Explanations oriented towards the emotions are now used to make sense of problems that before were illuminated through socio-economic or philosophical analysis" (2004: 21).

The genre offers a private utopia, a possible positive future, if readers are willing to follow the manual and make sufficient effort to change their mindsets and actions. Current popular literature and cultural production in general also make this offer. Strikingly, many authors and artists produce work in both self-help and popular genres, especially in movies and "chick lit." One of the most prominent such figures is the Swedish film director, writer, and lecturer Kay Pollak. His best-selling Att välja glädje: En bok om att få ett bättre liv (2001) begins with a prologue that articulates clearly an individualistic utopian concept: "What if paradise is essentially an interpersonal condition. A condition free from fear. A condition possible in every 'now'" (Pollak 2001:19). The stated goal primarily concerns developing oneself in order to become happier. There are striking similarities between Pollak and the Indian-American doctor and advocate of alternative medicine and spirituality Deepak Chopra, who also emphasizes the importance of mind control in order to obtain a happier, and in this case also a healthier, life (Chopra 2003). ${ }^{3}$

Pollak uses a religious language to express his version of a solipsistic new spirituality in which paradise is regarded as immanent, to be found on earth among those working on themselves hard enough. Like many authors in the self-help genre, Pollak uses medical science in a self-serving manner, claiming that medical research demonstrates that thoughts and imaginations have significantphysical effects. For instance, he refers to an unspecified English medical survey showing that 30 percent of cancer patients started to lose their hair after being told that they were given antineoplastic agents while they in fact were given saline solution (Pollak, 2001). ${ }^{4}$ The main message is that individuals can change their thoughts, feelings and behavior completely and in this way become better and happier people, no matter what their circumstances. This reasoning postulates that all change emerges from individual thoughts, which is basically consistent with a Cartesian dualistic understanding of human beings.

Pollak is the director of the very popular Så som $i$ himmelen (As it is in Heaven), a 2004 movie that has been called "an artistic presentation of Kay Pollak's books and lectures, a quick course in New Age management psychology" (Tidholm 2014: 324). The title is interesting as it alludes to a tendency discussed above, namely, that utopian ideals are now more often regarded as immanent, situated on earth. 
Tidholm later compares Pollak with Deepak Chopra and concludes that, while Chopra promotes the American dream, Pollak's ideas are rooted in Scandinavian soil. Tidholm discusses, for example, the way in which the "Law of Jante" is referred to. This "law" is most often used to describe Swedes and Scandinavians in a negative light. It first appears in a novel from 1933, En flyktning krysser sitt spor (A Fugitive Crosses his Tracks, 1936), by the Danish-Norwegian author Aksel Sandemose. In the novel, the "law" is expressed in lines such as: "You are not to think you are anything special" and "You are not to think you are as good as we are" (Sandemose 1936). These anti-bragging, conformativity principles have often been mocked in the last decades as an expression of a typically Scandinavian, or even Swedish, mentality related to social democratic politics and supposedly oppressing anti-individualism. ${ }^{5}$

Just as many of Chopra's concepts, Pollak's concept of choosing happiness is hierarchically and dualistically structured. Intuition is contrasted with reason, and belief with science. In other words, it is "neoliberalism in spiritual vestments", as Tidholm (2014: 328) puts it. The personal utopia presented in As it is in Heaven assumes an external savior, in the film embodied in the main character, the new male director of the local choir in a village in northern Sweden. This charismatic leader guides the local people to salvation, not unlike a contemporary self-help guru.

Other striking examples of the interaction between cultural production and self-help culture can be mentioned. The Swedish author Kajsa Ingemarsson had already written several best-selling novels in the chick lit genre when she started producing self-help literature and giving lectures. Her approach differs a bit from that of Pollak's, although Ingemarsson also emphasises spirituality, individual choice, and happiness. Nagonstans inom oss (Somewhere inside us, 2011) tells the story of a young woman with a brilliant career in financial advising who commits suicide, though her soul survives. The novel depicts her soul's thoughts and its dialogue with her guardian angel/life coach, Aruyan. The novel presents in a literary form ideas that are also treated in Ingemarsson's therapeutic self-help literature. Though dead, the main character finally gains vital insights into life and love. The moral of the novel is quite clear: Let go, move on, and-most importantly -learn to handle traumatic experiences from your childhood.

In Drömliv: Lycklig på riktigt (Dreamlife: happy for real, 2009) by Ingemarsson and Karin Nordlander, the authors instruct the reader in how to become happy by telling personal anecdotes from their own lives. A key word in this book is "soul":

The soul is your palace, your treasure, your magic place. The soul is the eternal part of you. It is your inner essence ... The soul is your divine part, your spirit, the highest aspect of yourself ... The soul is always 
clean. There are no evil souls and the soul cannot hurt. (Ingemarsson \& Nordlander 2009: 40f).

The "true self" is another repeatedly cited concept that the book aims to help the reader to find, claiming that the soul has been rejected by consumer society. Ingemarsson takes a paradoxical stance toward consumerism. She claims that one's true self and true happiness cannot be found by consuming (presumably with the exception of consuming Ingemarsson's products). By following the methods presented, the reader can achieve success on all levels in life, including the economic level:

Happy people obtain more opportunities, more doors to choose from. Who are we most likely to offer a job, the one projecting dissatisfaction and fear or the one showing confidence and happiness? Who would we prefer to marry, be friends with, do business with? (Ingemarsson \& Nordlander 2009:13)

Love, friendship, and economic transitions are treated as parts of an economistic way of thinking. This reasoning postulates a constant rejection of people who do not display happiness and confidence, not only in the labor market but also in social relationships in general.

Dreamlife: happy for real was followed by a trilogy entitled Hjärtats väg (Heartway), written by Ingemarsson alone. In the second volume, Modern mystik: Den dolda vägen till inre klarhet (Modern mysticism: the hidden way to inner clarity, 2014), the author declares her status as an autodidact before presenting an explicitly personal survey of mysticism: "My own definition of the term 'mystic' is that I search, imagine, feel, experience, and perceive something greater than what we normally call reality" (Ingemarsson 2014: 12). The book is illustrated, mostly with romantic photographs of the natural world taken by the author. Ingemarsson expresses her belief in reincarnation, and claims that there have always existed individuals who carry important keys to the riddles of life. She is, however, careful to assert that she "is not religious and will never be" (Ingemarsson 2014: 8).

Some observations can be made at this point: we find an individualistic version of late-modern spirituality, a belief in an internal higher self, and often a pseudoscientific vocabulary used to articulate a critique of science and reason. At the same time, an economistic way of thinking is presented as a seemingly natural starting point.

Common to the discourses presented by Ingemarsson, Pollak, and others, whether articulated in fiction, self-help literature, or other genres and media, is the emphasis on individuals and their responsibility for their own lives: structural 
or political explanations are rendered invisible. This makes New Age-inspired self-help literature a match for neo-liberalism. Several features are common to Pollak's and Ingemarsson's writings, such as an emphasis on the individual and the supposed "true self". There is one major difference, however: while Pollak's utopia is situated in the supposedly rational aspects of humanity, Ingemarsson emphasizes the irrational. While Pollak claims that individuals can completely control their thoughts and feelings, Ingemarsson encourages readers to come into closer contact with the irrational. She does not instruct readers in how to control their feelings, but rather in how to search for their soul, the supposed "higher self". Both Pollak and Ingemarsson intend to guide the reader to happiness, but they use different discourses to do so. The gap between Pollak's rational stance and Ingemansson's more irrational one is aligned with conventional binary gender norms. This does not mean that Pollak's reasoning is more rational: just that he utilizes a more rationalistic rhetoric.

The products that Ingemarsson offers are not restricted to literature. They include retreat journeys to Africa, lectures, and "magic" jewelry, which, it is claimed, helps the wearers find their true selves. Pollaks's webshop also offers other products: DVDs of courses and lectures. Also in this respect, the two authors are examples from a somewhat new field in which cultural or artistic production goes hand-in-hand with new spirituality and self-help literature.

\section{Mom Lit in a Swedish Context}

Chick lit is a popular genre with strong connections to self-help literature. Chick lit usually deals with young, urban middle-class women struggling to achieve a successful career and a flourishing (most often heterosexual) love life. Friendship, shopping, and fashion and makeup are other central motifs in this literature, which is usually, written by females targeting female readers. Parallels have been drawn with romance literature and advice literature from the 19th century (Larsson 2007: 80, 84). Literary scholar Yvonne Leffler has examined Swedish chick lit as an expression of sociocultural commentary, regarding it as part of today's self-help industry, yet anchored in a long tradition of manuals of manners for women. Leffler points out that the Swedish chick lit novels often deal with matters such as shopping and sex from a middle-class female point of view, as glamorous Anglophone chick lit does. In contrast, Swedish chick lit, according to Leffler "teaches its female audience how to deal with much more serious matters, such as personal crises; family problems; and various mental problems, such as depression and feelings of inferiority" (Leffler 2014: 157).

Literature on young motherhood, known as "mom lit" or "mommy lit", is an expansive, popular hybrid subgenre of chick lit (Nilsson \& Ehriander 2012). The 
term is used to denote several types of writing: fiction, life writing and self-help literature, in the same way as the term "chick lit" is used. Social norms and issues of family and working life, as well as various aspects of health and wellbeing, are analysed in mom lit novels and mom chronicles or blogs, all of which are subsets of mom lit. In general, mom lit refers to literature telling of mothers' everyday lives with their, often young, children (A younger, less common subset is dad chronicles/blogs, which lie beyond the scope of this article).

Mom lit is similar to the genres discussed above, although with a more prominent biographical character. Mom lit is part of a popular literary trend, just as chick lit and self-help literature are. The genre is related also to older prescriptive literature aimed at young women (Larsson 2007). A significant feature of the genre is the advocatory tone regarding issues of health in a broad sense-including wellbeing, physical exercise, and, in particular, stress management. Mom lit repeatedly attempts to convince the reader/mother that she is good enough, despite current ideals, norms, and internalized social expectations. The multiple focus on shopping, fashion, and overall perfection, together with its self-help aura, make this a paradoxical genre: "Mom lit exposes, often humorously, the cost of aspiring to yummy motherhood; yet the solutions found to the problem of gelling professional and 'natural' maternal identity generate some disturbing myths", as Imelda Whelehan (2012: 156) puts it. Her Anglo-American material expresses a similar nostalgic, paradoxical femininity and ideal of motherhood, but differs in a significant way: "contemporary mom lit seems to suggest that you can't be a good mother and good at something else simultaneously" (Whelehan 2012: 157). Yet, also Swedish mom lit depicts conflicts between self-development and responsibilities toward the family unit. Stephanie Harzewski claims that this characterizes the subgenre as such, and hence makes it slightly less light-hearted than chick lit in general (Harzewski 2011:170). The Swedish examples of mom lit in the material we have analyzed take as their starting point this combination of good performance in both motherhood and other fields, emphasizing the difficulties and suffering that this entails. Below, we explore more deeply how the advocating aspects of mom lit are manifested, and discuss some paradoxical features of the genre.

Among the most popular writers of mom lit in Sweden we find actors, broadcasters, journalists, and others who reach a vast number of readers, describing and reflecting on their family life. In the writing of Mia Skäringer (popular actor and comedian), Martina Haag (actor and popular writer of chick lit), and Ann Söderlund (journalist and television anchor), the family motif is merged with personal reflections on career, health, and (to some extent) spirituality. In this article we scrutinize a selection of anthologized non-fiction chronicles and other short texts, mostly republished material that originally appeared in magazines, 
newspapers, and blogs. The texts deal with serious subjects, but are characterized by their humorous, often ironic undertone, just like mom lit in general. A salient theme is the quest for happiness, an ideal closely connected with family, career, and health (Ahmed 2010: 46; Hermansson 2014: 218). The three writers mentioned above have also occasionally blogged at mama.nu, the web version of the Swedish paper magazine Mama. Notably, all these writers have also written for various health blogs (such as jogg.se and topphalsa.se), while Haag has published an advocatory book on running (Haag 2012).

In mom lit and in advertising, much emphasis is placed on legitimizing individual enjoyment-seeking through consumption. This is expressed in the currently emblematic phrase "because you're worth it". This phrase stresses enjoyment as something you-but perhaps not everyone-deserve. This is, in turn, related to the self-boosting theme of these writings. In Skäringer's Dyngkait och hur helig som helst ("Horny and as holy as one can be", 2009/2010), the first-person narrator describes her separation from the father of her children. One passage tells of a journey by car with her new boyfriend and their children from earlier relationships. The narrator seems to be content: "We ought to get a bonus point in heaven because we have done so well. So far. Take the fattest felt-tip pen and write plus signs on us. Pat us on our backs! Although we committed a sin and gave up our REAL families, we are worth it" (Skäringer 2009/2010: 11).

The above quotation is clearly intended to affirm family constructions that differ from the traditional nuclear family. It uses Christian language, although somewhat ironically, and illustrates indirectly how shame and pride go hand-in-hand. Also, while begging for admiration, Skäringer implies that some families are still not worth admiring. A question remains, however: Who is not worth "a bonus point in heaven"? Those who do not strive enough? Those who fail and cannot recover? Furthermore, the quotation clarifies how important it is to receive this immanent "bonus point", in other words, other people's approval is emphasized despite the declared intention. This kind of reasoning might easily lead to a desire for vengeance. Illouz states that therapeutic culture brings to the fore Max Weber's ideas of how psychology completes religious aims to justify suffering, by applying "the most powerful preservation of the status quo, namely the retrospective explaining and therefore legitimizing of good or bad fortune by hidden virtue or vice. [...] In the therapeutic ethos there is no such thing as senseless suffering and chaos, and this is why, in the final analysis, its cultural impact should worry us" (Illouz 2008: 247).

In her writings on the discourse of happiness, Sara Ahmed claims that there is a strong connection between the experience of happiness and what is thought to create happiness. If one accepts that correlation implies causation, social norms 
become social goods. If someone cannot meet the standards of happiness, it is not the ideals that are the problem, but the individual (Ahmed 2010). Slavoj Žižek (1996) expresses similar ideas, but claims that pleasure is a current duty. Both Ahmed and Žižek believe that people are under a social obligation to be happy or/ and to enjoy life. An important source of this happiness is, Ahmed (2010) writes, the family.

A frequent activity of many Swedish families, at least those with small children, is known as fredagsmys. ${ }^{6}$ This usually involves the family gathering on a Friday evening, consuming snacks and watching tv, though the content varies from family to family. Martina Haag writes ironically about her efforts to create a perfect sweet Friday, as she defined it, which ended in total chaos despite (or because of) her husband's elaborate preparation of hickory-grilled salmon. The details given in the texts, such as hickory-grilled salmon and descriptions of the children's hobbies, reveal the social class to which Haag belongs. It is obvious that the three writers mentioned, although they come from different backgrounds, write from a certain socio-economic position in which a certain economic standard is taken for granted, thereby consolidating certain standards of class and gender.

Skäringer, Haag, and Söderlund all take their starting points in stress that they have experienced, both at work and in family life. The stress has arisen as a consequence of trying to be good, healthy mothers and partners. Haag ironically describes her mind-blowingly stressful drive to the meditation center where she takes classes to become more relaxed, even though everyday issues continually occupy her mind: the children's rainwear forgotten at preschool, the need to call the vet, plans to fetch her son's violin, a never-ending shopping list, and so on. The meditation is depicted as counterproductive, constituting just another obligation that increases, rather than releases, stress-which is the very unsacred goal (Haag 2006).

Skäringer's writing, on the other hand, embraces alternative therapeutic methods such as healing massage. In her republished blog from 2010, she describes the benefits gained from her private yoga classes, while she claims that running exercise is her "antidepressant" (Skäringer, 2011: 19). Her goal, she says, is to become happy, and her methods seem to be working: "I feel pretty happy. On the right course" (Skäringer, 2011: 12). Skäringer sees happiness and wellbeing in the context of her career (as an artist and actor), family life, and physical exercise. Most importantly, she emphasizes cultivating "presence" and being true to oneself, ideals that are clearly familiar as key discourses in current self-help literature and new spirituality. Similar intentions of finding a supposed true inner self are also found in the manifestations of the Enneagram discussed above. 
Unlike Ingemarsson and Pollak, the authors of the mom lit studied here do not offer the reader any guidance. This applies most clearly to Skäringer, who often addresses the reader directly: "I want to cool down. Become happier, freer, more supple. More independent. Less controlling and more bold. If you'd like to, please join me!" (Skäringer 2011: 4). By addressing her readers as equals, not claiming to have more knowledge or ability than them, Skäringer stresses in this passage the connection between her writing and self-help literature.

A common denominator of the literary examples mentioned here is the ideal of authenticity and individual freedom. Individual liberation is a question of becoming truer to oneself. To do this, one must invest in oneself, be it through physical exercise or spiritual practice.

The emphasis on authenticity might explain why Skäringer received such massive criticism when it became known that her blog, exploring an unhealthy obsession with health and published in the Swedish national tabloid newspaper Aftonbladet, was sponsored by ProViva, a company best known for producing probiotic fruit drinks. Skäringer did not seem so authentic after all, and the sponsorship becoming public knowledge harmed, at least temporarily, her own brand (see, for example, Thomsen 24 March 2014; Domellöf Wik 26 April 2014).

The quest for happiness in love, health, and/or family life manifested in mom lit reveals a paradox: on one hand, gender equality is taken as a starting point and emphasis is placed on it; while on the other hand, gender differences are accentuated and may be depicted as sexually attractive. Söderlund, for example, writes: "A man treating the hammer and the power drill like a Ninja is bloody sexy" (Söderlund 2007: 67, capital letter in the original). In another book, however, Söderlund says that we ought to "stub out all gender roles" (Söderlund 2010: 50).

In Lyckliga i alla sina dagar: Om pengars och människors värde (Happily ever after: on the value of money and people, 2012), literary scholar and public debater Nina Björk examines current dreams and ideals in the context of our current market-based society. She describes what she describes as a "shift", after which social utopias are banned but individual dreams are promoted (though these dreams are not particularly individual, but usually in line with current ideology, e.g. consumerism). According to Björk, a vast consumer society is eager to make the dream of changing the individual self a question of consuming the right products, services, journeys, and experiences. Analyzing the first issue of Mama, in 2003, she notes that the magazine, which contains a huge number of articles about consumption, demonstrates a striking disparity between lessons and dreams: it claims repeatedly that it is not giving any lessons, while promoting luxury in everyday life and encouraging dreams. These dreams, according to Björk, are all about consuming: "We obey when shopping ... A mum who considers herself deserving of pink sunglasses from Versace at a price of 1775 Swedish crowns is 
basically a very obedient mum, following an irresistible directive" (Björk 2012: 39).

In mom chronicles, especially in the blogs examined here, the commercial allusions are striking, and luxury shopping is an unquestioned practice that also serves as a dream. This dream may be particularly relevant for readers who cannot afford to buy the named products or services.

Paradoxically, both the Enneagram and mom lit presuppose an individual core, while simultaneously providing advice on how to shape the self. This shaping is primarily mental, but also contains, especially in mom lit, physical shaping. Mom lit functions as counseling literature, intended to help the reader cope with society today. It promotes an image of good mothers, who endeavor to combine career and parenthood while keeping up a flourishing sex life, a healthy body, and an organized home, rather than speaking out, rejecting the whole framework of ideals or mobilizing for a better society, for class or gender equality, for a sustainable world. According to these writings, however, the good life is not about being good-looking or having a "perfect" body, although such ideals are, quite paradoxically, featured. The good life is essentially about loving oneself and being "true" to oneself: "Give the love to yourself. Focus it inwards" (Skäringer 2011:167).

\section{Concluding Remarks}

Popular religion and literature have been profoundly affected by the psychologizing and intimization that are part of contemporary Western culture more generally, and particularly associated with what Peter Conrad and Frank Füredi refer to as the increasing medicalization of and therapeutic turn in Western society (Füredi 2004; Conrad 2007). This means that new types of authority are becoming established that are no longer associated with existing societal institutions. Such authorities must find other ways to legitimize their power, for example, by implicitly or explicitly invoking a particular natural or medical science. In contemporary religious life, such a development is closely related to new manifestations of the New Age movement and the "spiritual market" (Carrette and King 2005).

Here we highlight certain common features in some forms of popular cultural production. Fiction, self-help literature, and popular life writing (such as mom lit) offer ways to help individuals become better people, while referring to central concepts of new spirituality. These products simultaneously consolidate dominant ideals of happiness, gender, family life, health, and so forth. We have examined how these paradoxical stances are manifested, and described the way in which they use personal, humoristic, and ironic points of view to criticize current ideals of perfection, while still (re)presenting individualistic, consumeristic ideals and a belief in an "inner self" similar to what we find in new spirituality. 
The quest for the good life is closely aligned with other turns in Swedish society. These may be referred to as inward, therapeutic, and subjective turns, focusing on the nuclear family and intimate relationships, but primarily oriented toward the "inner core self." The material examined here claims that unhealthy ideal beauty standards that overemphasize diet and other people's approval should not be cured by, for example, social alliances or regulations, but by individual choice or inward journeys. This is most evident in the work of Pollak and Ingemarsson. The utopian relief from an overwhelming pressure experienced both at work and in family life is now to be found inside, at least by those people who practice sufficiently assiduously and who follow the correct instructions. In mom lit, an individual utopia can be reached if the author/reader changes her attitude, rather than by material or social change. One paradox found in the material is a recurring criticism of the consumer society-a criticism that is articulated in terms of an economistic logic in which the values of people, actions, and phenomena are based on what the individual can gain from them, usually in terms of happiness or wellbeing.

The analysis of different Enneagram manifestations has made it clear that these new spiritual movements place previous transcendental goals within the individual, immanent self. The current utopias are synonymous with the "I," the real, true self who can be found behind social masks. It can be noted that the individual therapeutic struggle to reach this utopia is served by a consumerism-based society, offering services and products by which to discover this inner self. Furthermore, this understanding of the "true self" relies on a culturally based discourse in which medicalized, therapeutic language-what Michel Foucault called "bio-power" or "bio-politics"-defines humanity and the human condition. In fact, what we see today is, to a greater extent than before, an embodiment, intimization, and reproduction of the medicalized, bio-political discourse. The Swedish popular literature and religion examined here are both expressions of this discourse and important forms of new authority when it comes to describing new utopian ideals for people to relate to in everyday life, at work, in family life, and in their life expectations and dreams.

Daniel Enstedt is senior lecturer in religious studies at the University of Gothenburg, Sweden. Enstedt's research mainly focuses on Contemporary Religion and the Sociology of Religion. He received his $\mathrm{PhD}$ in 2011, on completion of a thesis on the reception of the Church of Sweden's decision to introduce a special blessing ceremony for same-sex unions. Since then he has been working on two research projects: Leaving Islam: Apostasy, freedom of religion and conflicts in a multireligious Sweden, together with professor Göran Larsson, and The Good 
Life. Contemporary views on family life and life at work, together with Kristina Hermansson. Enstedt co-edited 'Annual Review of the Sociology of Religion. Vol. 6, Religion and Internet' (2015) with Göran Larsson and Enzo Pace.

Kristina Hermansson is senior lecturer in comparative literature at the University of Gothenburg, specializing in children's fiction. She was coordinator at the Centre for Interdisciplinary Gender Research at Gothenburg University, 2015-2017. Her latest research publications are focused on contemporary Scandinavian picture books and so called norm critical children's literature. This article is part of the project The Good Life, in which Hermansson (together with Daniel Enstedt) examines ideas about family life and life at work that has been manifested in Sweden since the start of the millennium.

\section{NOTES}

${ }^{1}$ See also a special edition of Culture Unbound, Vol 6, 2014, on Therapeutic Culture.

${ }^{2}$ All translations from Swedish and Danish have been made by the authors.

${ }^{3}$ The Swedish translation of Chopra's book is entitled Att välja glädjen. Pollak's Att välja glädje also contains a quotation, claimed to have been recorded at one of Chopra's lectures in Stockholm.

${ }^{4}$ Pollak does not, however, give any references to any of the many cases he refers to, nor does he discuss the the impact of social or other environmental factors have on on our minds.

${ }^{5}$ Christer Ekholm describes this, in a Scandinavian context widely spread part of the novel, as "a pastiche of the decalogue, put into the mouth of the working class collective oppressing minorities in a small village" (Ekholm 2009:10). The "law" of Jante is brought to the fore in contemporary self-help literature, such as Tomas Gunnarsson's Att överlista Jante. Om konsten att lyfta sig själv och andra. [Outsmarting Jante: On the art of lifting oneself and others, 2012] and Eva Träff's Tryggt hav. En bok om mera mod, mindre Jante och personlig utveckling [Safe sea: A book on more courage, less Jante and personal development, 2014].

6 "Fredagsmys" is a Swedish popular phenomena, meaning a casual family gathering on Friday nights. Fredagsmys most often takes place at home and is associated with taco dinner, snacks and watching tv.

${ }^{7}$ For a further discussion about consumerism, self-help literature and new spirituality, see Paul Heelas' Spiritualities of Life (2008), and for a discussion about power and authority in relation to the Enneagram online, see Enstedt (2015b: 60-61). 


\section{Culture Unbound}

Journal of Current Cultural Research

\section{References}

Ahmed, Sara (2010): The Promise of Happiness, Durham \& London: Duke University Press.

Almqvist, Kurt and Hammer, Olav (1999): Jung och det andliga, Stockholm: Svenska förl.

Aristotle (2011): Aristotle's Nicomachean Ethics, Chicago: University of Chicago Press.

Bates, Victoria, Bleakley, Alan and Goodman, Sam (2014): Medicine, Health and the Arts: Approaches to the Medical Humanities, London \& New York: Routledge.

Berger, Peter L., Davie, Grace and Fokas, Effie (2008): Religious America, Secular Europe? A Theme and Variations, Aldershot, England: Ashgate.

Bernéli, Marie (2009): Enneagrammet: om skapelse, brustenhet och helande, Malmö: Marie Bernéli.

Björk, Nina (2012): Lyckliga i alla sina dagar: Om pengars och människors värde, Stockholm: Wahlström \& Widstrand.

Bovbjerg, Kirsten Marie (2007): 'De menneskelige potentialer i en "stresstid", Joel Haviv (ed) Medarbejder eller modarbejder: religion i moderne arbejdsliv, Århus: Klim.

Carrette, Jeremy R. and King, Richard (2005): Selling Spirituality: The Silent Takeover of Religion, London: Routledge.

Chopra, Deepak (2003): The Spontaneous Fulfillment of Desire: Harnessing the Infinite Power of Coincidence to Create Miracles, New York: Three Rivers Press.

Claeys, Gregory (2010): The Cambridge Companion to Utopian Literature, Cambridge: Cambridge University Press.

Conrad, Peter (2007): The Medicalization of Society: On the Transformation of Human Conditions into Treatable Disorders, Baltimore, MD: Johns Hopkins University Press.

Cullberg, Johan (2001): Dynamisk psykiatri i teori och praktik, Stockholm: Natur och kultur.

Defoe, Daniel (1986 [1719]): The Life and Adventures of Robinson Crusoe, London: Puffin

Culture Unbound Volume 6 (2014): on Therapeutic Culture, http://www. cultureunbound.ep.liu.se/v6/a01/cu14v6a01.pdf.

Demerath, NJ III (2007): "Secularization and Sacralization Deconstructed and Reconstructed", James A. Beckford and NJ Demerath (eds) The SAGE Handbook of the Sociology of Religion, London: SAGE.

Domellöf, Wik Maria (2014): 'Slutbloggat på Proviva för Skäringer', Göteborgs-Posten, 26 April 2014.

Ekholm, Christer (2009): 'Lokaliseringen som grepp-exemplen Sandemose och Camus', NORLIT 2009 Codex and Code, Aesthetics, Language and Politics in an Age of Digital Media, Stockholm, August 6-9, 2009, http://www.ep.liu.se/ ecp/042/015/ 171.

Enstedt, Daniel (2015a): 'Enneagramreceptionen i Sverige', Chaos: Skandinavisk tidsskrift for religionshistoriske studier, 62: 2 .

Enstedt, Daniel (2015b): 'Sleepwalkers and Higher Selves: The Mediatisation of "Personality" and "Essence" in Online Enneagram Teachings', Daniel Enstedt, Göran Larsson \& Enzo Pace (eds) Annual Review of the Sociology of Religion: Vol. 6, Religion and Internet, Leiden: Brill.

Foucault, Michel (2002 [1970]): The Order of Things: An Archaeology of the Human Sciences, London: Routledge.

Frisk, Liselotte and Åkerbäck, Peter (2013): Den mediterande dalahästen: religion på nya arenor i samtidens Sverige, Stockholm: Dialogos.

Frisk, Liselotte (1998): Nyreligiositet i Sverige: ett religionsvetenskapligt perspektiv, Nora: Nya Doxa. 


\section{Culture Unbound}

Journal of Current Cultural Research

Füredi, Frank (2004): Therapy Culture: Cultivating Vulnerability in an Uncertain Age, London: Routledge.

Giddens, Anthony (1991): Modernity and Self-identity: Self and Society in the Late Modern Age, Cambridge: Polity Press.

Haag, Martina (2006): Martina-koden, Stockholm: Piratförlaget.

Haag, Martina (2012): Heja, heja, Stockholm: Piratförlaget.

Hammer, Olav (1999): Profeter mot strömmen: essäer om mystiker, medier och magiker $i$ vår tid, Stockholm: Wahlström \& Widstrand.

Hammer, Olav (2010): På spaning efter helheten: New Age, en ny folktro? Stockholm: Dejavu.

Hanegraaff, Wouter J. (1996): New Age Religion and Western Culture: Esotericism in the Mirror of Secular Thought, Leiden: E.J. Brill.

Harrington, Anne (2008): The Cure Within: A History of Mind-body Medicine, New York: W.W. Norton \& Co.

Harzewski, Stephanie (2011): Chick lit and postfeminism, Charlottesville: University of Virginia Press.

Haviv, Joel (2007): 'Medarbejder eller modarbejder: Religion som legitimering af økonomisk handlen', Joel Haviv (ed) Medarbejder eller modarbejder: religion $i$ moderne arbejdsliv, Århus: Klim.

Heelas, Paul (2008): Spiritualities of Life: New Age Romanticism and Consumptive Capitalism, Malden, MA: Blackwell Pub.

Heelas, Paul (2002): "The Spiritual Revolution: From "Religion" to "Spirituality", Linda Woodhead (ed) Religions in the Modern World: Traditions and Transformations, London: Routledge.

Hermansson, Kristina (2014): 'Lyckodrömmar. Familjen karriären och jaget hos Mia Skäringr, Martina Haag och Ann Söderlund', K Hermansson, C Lenemark \& C. Pettersson (eds), Liv, lust och litteratur: Festskrift till Lisbeth Larsson, Göteborg: Makadam Press.

Hornborg, Anne-Christine (2010): 'Marknadsföring av natur, hälsa och rituellt helande i det senmoderna Sverige', Anne-Christine Hornborg (ed), Den rituella människan: flervetenskapliga perspektiv, Linköping: Linköping University Electronic Press.

Hornborg, Anne-Christine (2012): Coaching och lekmannaterapi: en modern väckelse? Stockholm: Dialogos.

Hornborg, Anne-Christine (2014): 'Att få flow i livet: Mind-body-terapin och coaching som nya helandemetoder', J Moberg \& G Ståhle (eds), Helig hälsa: helandemetoder $i$ det mångreligiösa Sverige, Stockholm: Dialogos.

Illouz, Eva (2008): Saving the Modern Soul: Therapy, Emotions, and the culture of Self-help, Berkeley: University of California press.

Ingemarsson, Kajsa \& Nordlander, Karin (2009): Drömliv: Så blir du lycklig på riktigt, Stockholm: Norstedts.

Ingemarsson, Kajsa (2011): Någonstans inom oss, Stockholm: Norstedts.

Ingemarsson, Kajsa (2014): Modern mystik: Den dolda vägen till inre klarhet, Stockholm: Bladh by Bladh.

Johannisson, Karin (2009): Melankoliska rum: om ångest, leda och sårbarhet $i$ förfluten tid och nutid, Stockholm: Bonnier.

Kardemark, Wilhelm (2013): När livet tar rätt form: om människosyn i svenska hälsotidskrifter 1910-13 och 2009, Göteborg: Göteborgs universitet.

Lapid-Bogda, Ginger (2010): Bringing Out the Best in Everyone You Coach: Use the Enneagram System for Exceptional Results, New York: McGraw-Hill.

Larsson, Lisbeth (2007): 'Från Rådgifvare till Chick-lit. Den romantiska berättelsens förändringar', S Ekman, M Malm \& B Stenberg (eds), Den litterära textens förändringar: Studier tillägnade Stina Hansson, Höör: Symposion.

Lasch, Christopher (1978): The Culture of Narcissism: American Life in an Age of Diminishing Expectations, New York: Norton. 


\section{Culture Unbound}

Journal of Current Cultural Research

Leffler, Yvonne (2014): 'Chic Lit as Healing and Self-Help Manual? Marie Demker, Yvonne Leffler \& Ola Sigurdson (eds), Culture, Health, and Religion at the Millennium: Sweden Unparadised, New York: Palgrave Macmillan.

More, Thomas (2012 [1516]): Utopia, London: Penguin Books.

Norris, Pippa and Inglehart, Ronald (2011): Sacred and Secular: Religion and Politics Worldwide, Cambridge: Cambridge University Press.

Palmer, Helen (1995): The Enneagram in Love and Work, New York: HarperCollins.

Plank, Katarina (2011): Insikt och närvaro: akademiska kontemplationer kring buddism, meditation och mindfulness, Lund: Lunds universitet.

Plank, Katarina (2014): Mindfulness: tradition, tolkning och tillämpning, Lund: Nordic Academic Press.

Pollak, Kay (2001): Att välja glädje: En bok om att få ett bättre liv, Sundbyberg: Hansson Pollak videoutbildning.

Pollak, Kay (2004): Så som i himmelen, Stockholm: SF.

Rieff, Philip (1968): The Triumph of the Therapeutic: Uses of Faith after Freud, New York: Harper \& Row.

Riso, Don Richard and Hudson, Russ (1999): The Wisdom of the Enneagram: The Complete Guide to Psychological and Spiritual Growth for the Nine Personality Types, New York: Bantam Books.

Sigurdson, Ola (2014): 'Hygiene as Metaphor: On Metaphorization, Racial Hygiene, and the Swedish Ideals of Modernity', Marie Demker, Yvonne Leffler \& Ola Sigurdson (eds), Culture, Health, and Religion at the Millennium: Sweden Unparadised, New York: Palgrave Macmillan.

Skäringer, Mia (2009/2010): Dyngkåt och hur helig som helst, Stockholm: Forum.

Skäringer, Mia (2011): Avig Maria, Stockholm: Forum.

Söderlund, Ann (2007): På spaning med Ann, Stockholm: Natur \& Kultur.

Söderlund, Ann (2010): Men vi knullar ju ändå inte, Stockholm: Natur \& Kultur.

Thomsen, Dante, 'Aftonbladets debattchef om Proviva-debaclet: "Vi trodde på Mia Skäringer"', Dagens Media, 24 March 2014.

Tidholm, Po (2014): 'Så som i en reklamfilm', In Norrland: Essäer och reportage, Luleå: Teg publishing.

Vieira, Patricia and Marder, Michael (2012) Existential Utopia: New Perspectives on Utopian Thought, London: Continuum.

Whelehan, Imelda (2012): "'Shit and stringbeans",Boredom and Babies. Bad Mothers in Popular Women's Fiction Since 1968', Elizabeth Podnieks (ed), Mediating Moms: Mothers in Popular Fiction, McGill-Queens University Press.

Wiktorén, Elisabeth (2007): Enneagrammet och de nio livsstrategierna, Västerås: Ica.

Žižek, Slavoj (1996): Sex essäer om kvinnan, kulturen och makten, Stockholm: Natur och kultur. 